\title{
Apple Pollen Tube Growth Rates Are Regulated by Parentage and Environment
}

\author{
Candace N. DeLong, Keith S. Yoder, and Leon Combs \\ Alson H. Smith Jr. Agricultural Research and Extension Center, Virginia Polytechnic Institute and \\ State University, 595 Laurel Grove Road, Winchester, VA 22602
}

Richard E. Veilleux

Department of Horticulture, Virginia Polytechnic Institute and State University, Latham Hall, $220 \mathrm{Ag}$ Quad Lane, Blacksburg, VA 24061

\author{
Gregory M. Peck ${ }^{1}$ \\ Horticulture Section, School of Integrative Plant Science, Cornell University, 121 Plant Science \\ Building, Ithaca, NY 14853
}

\begin{abstract}
Additional INDEX words. developmental biology, Malus $\times$ domestica, crop load management, bloom thinning
Abstract. A greater understanding of apple (Malus $\times$ domestica) pollen tube growth rates can improve crop load management in commercial orchards. Specifically, applications of caustic bloom-thinning chemicals need to occur when enough, but not too many, flowers have been fertilized to achieve crop load densities that balance yields with marketable fruit sizes. In this study, the pollen tube growth rates of five crabapple (Malus sp.) cultivars were measured in the styles of three maternal cultivars at 12, 18, 24, and $30{ }^{\circ} \mathrm{C}$ after 24 hours in a growth chamber. Pollen tube growth rates were greatest for 'Selkirk' and 'Thunderchild' at $12{ }^{\circ} \mathrm{C}$, and greatest for 'Indian Summer', 'Selkirk', and 'Thunderchild' at $24^{\circ} \mathrm{C}$. Pollen tube growth increased with increasing temperatures until $24^{\circ} \mathrm{C}$. There were minimal pollen tube growth rate increases between 24 and $30^{\circ} \mathrm{C}$. Overall, 'Snowdrift' had the slowest pollen tube growth rate of the five evaluated crabapple genotypes. At 24 and $30{ }^{\circ} \mathrm{C}$, 'Indian Summer' and 'Thunderchild' pollen tubes reached the base of the style most frequently, and 'Snowdrift' pollen tubes the least frequently. Pollen tube growth rate was also influenced by the maternal cultivar, with Golden Delicious having relatively faster pollen tube growth than Fuji at 24 and $30^{\circ} \mathrm{C}$. Interactions among paternal and maternal genotypes as well as temperature after pollination reveal complex biological and environmental relationships that can be used to develop more precise crop load management strategies for apple orchards.
\end{abstract}

Apple pollination occurs when pollen is transferred, often by an insect vector, from the anthers of one blossom to the stigma of another. After pollen grains are deposited, they are rehydrated by stigmatic secretions, and pollen tube growth begins (Dennis, 2000; Jackson, 2003). Genetically compatible pollen tubes grow through the stigma and style and toward the ovaries. At the end of the style, the pollen tube enters the ovary through the micropyle, where two sperm cells are released into the ovule. Fertilization occurs when one nucleus fuses with the egg cell, and the second nucleus fuses with the embryo sac, initiating seed formation (Dennis, 2000). Investigations into apple pollen biology have been underway for over a century (Adams, 1916) and have recently been reviewed by Ramírez and Davenport (2013).

In commercial apple orchards, cross-pollination between two distinct genotypes results in greater fertilization rates and thus a greater fruit set, even in orchards containing self-fertile cultivars (Dennis, 2003). Various Malus species, colloquially referred to as crabapples, are preferred pollinizers in commercial orchards due to their long bloom periods, disease resistance,

Received for publication 13 May 2016. Accepted for publication 29 Aug. 2016. This project was funded by Virginia Agricultural Experiment Station and Virginia Tech's Department of Horticulture.

We thank Abby Kowalski, Ashley Thompson, Taylor Mackintosh, and David Carbaugh for their assistance in the field and lab, Mizuho Nita for guidance with statistics, and Roger Harris and Tony Wolf for review of the manuscript.

${ }^{1}$ Corresponding author. E-mail: gmp32@cornell.edu. and abundant pollen production (Fitzgerald, 2005). In particular, the crabapple Malus baccata 'Manchurian' has been widely planted in commercial orchards as a pollinizer. However, it has fallen into disfavor in recent years due to its high susceptibility to canker diseases, which could limit apple exports into Asian markets (Hansen, 2014). Other popular crabapple pollinizers include 'Snowdrift', 'Thunderchild', 'Indian Summer', 'Mt. Blanc', 'Wickson Crab', and 'Chestnut Crab'.

The pollen tube growth rate of 'Snowdrift' has been used to develop a temperature-driven pollen tube growth model that can predict the time between pollination and fertilization (Peck et al., 2016; Yoder et al., 2013). The model is now being used by commercial apple growers to precisely calculate when to apply bloom-thinning chemicals (Lehnert, 2014). The majority of bloom-thinning chemicals are caustic and prevent pollination or fertilization by destroying flower parts and inhibiting pollen germination and pollen tube growth. Liquid lime sulfur (calcium polysulfide) is the most studied and commercially used bloom-thinning chemical (McArtney et al., 2006).

Although Snowdrift pollen tube growth can differ by as much as 3-fold among maternal cultivars, published reports on the pollen tube growth rates of other crabapple species and cultivars are limited (Embree and Foster, 1999; McArtney et al., 2006; Stott, 1972; Williams, 1965). Successful application of blossom-thinning chemicals is highly dependent on understanding the rate of pollen tube growth among different pollen donor genotypes (Jackson, 2003). Analyzing the pollen 
tube growth rates of additional pollen donors could contribute to the selection of improved pollinizers for apple orchards.

The objectives of this study were to determine how pollen tube growth rates were affected by paternal (pollen source) and maternal cultivars, temperatures after pollination, and the interaction among these factors. We did this by comparing the pollen tube growth rates of five crabapple cultivars on three maternal culinary apple cultivars at four temperatures.

\section{Materials and Methods}

Experiments were conducted at Virginia Tech's Alson H. Smith Jr. Agricultural Research and Extension Center (AREC) in Winchester, VA. In 2013 and 2014, pollen was collected from mature 'Evereste', 'Indian Summer', 'Selkirk', 'Snowdrift', and 'Thunderchild' trees located at the AREC. Only healthy blossoms in the late pink flower stage (when petals still covered the sexual organs and before dehiscence of anthers) were used (Chapman and Catlin, 1976). Pollen was collected by removing anthers from the blossoms using a fine-toothed comb, allowing them to air-dry, and then pressing the anthers through a 200-mesh sieve (74 $\mu \mathrm{m}$ between wires). Pollen was stored in microcentrifuge tubes at $-12{ }^{\circ} \mathrm{C}$ until use. Pollen collected in 2013 and 2014 was combined for each crabapple cultivar. Pollen viability was scored in two samples for each crabapple cultivar after $24 \mathrm{~h}$ at $21{ }^{\circ} \mathrm{C}$ on an agarose $\left(10 \mathrm{~g} \cdot \mathrm{L}^{-1}\right)$, sucrose $\left(100 \mathrm{~g} \cdot \mathrm{L}^{-1}\right)$, and boric acid $\left(10 \mathrm{mg} \cdot \mathrm{L}^{-1}\right)$ medium by calculating the percent germination (Williams and Maier, 1977).

Mature 'Autumn Rose Fuji'/'M.9', 'Golden Delicious'/ 'M.27', and 'Cripps Pink'/'M.9' trees grown in 19-L root bags (Lacebark, Stillwater, OK) were the maternal cultivars selected for this study. Whole trees (including the bagged root system) were removed from the orchard in Jan. 2015, placed in 19-L buckets, and kept in cold storage to accumulate sufficient winter chill hours to complete endodormancy. 'Cripps Pink' and 'Fuji' trees were kept at $4.4{ }^{\circ} \mathrm{C}$ for $400 \mathrm{~h}$, and 'Golden Delicious' trees were kept at $4.4^{\circ} \mathrm{C}$ for $700 \mathrm{~h}$; after the chilling hours had been met, trees were moved into a greenhouse (mean temperature $24^{\circ} \mathrm{C}$ ) to force bloom.

Maternal flowers used in the experiment were selected during the late pink flower stage. During each temperature trial, pollen from the five paternal cultivars was hand-pollinated onto 35 flowers from each maternal cultivar; seven unique pollinated flowers for each paternal cultivar treatment. An additional seven emasculated, nonpollinated flowers were left on the tree to serve as nonpollinated controls. All side blooms and extra flower clusters were removed from the tree to prevent cross-contamination. Flowers were tagged to identify the pollen source, and a sterilized, size 6 artist's brush was used to apply pollen directly to the stigma. Pollen was applied in a uniform way until pollen grains were visible on the stigma. Immediately after pollination, trees were placed into a temperature-controlled growth chamber (Intellus Control System; Percival Scientific, Perry, IA) for $24 \mathrm{~h}$ under a 12 -h photoperiod. For each maternal cultivar, the experiment was repeated at four ambient air temperatures: $12,18,24$, and $30^{\circ} \mathrm{C}$ for the duration of the experiment. After $24 \mathrm{~h}$ in the growth chamber, flowers were

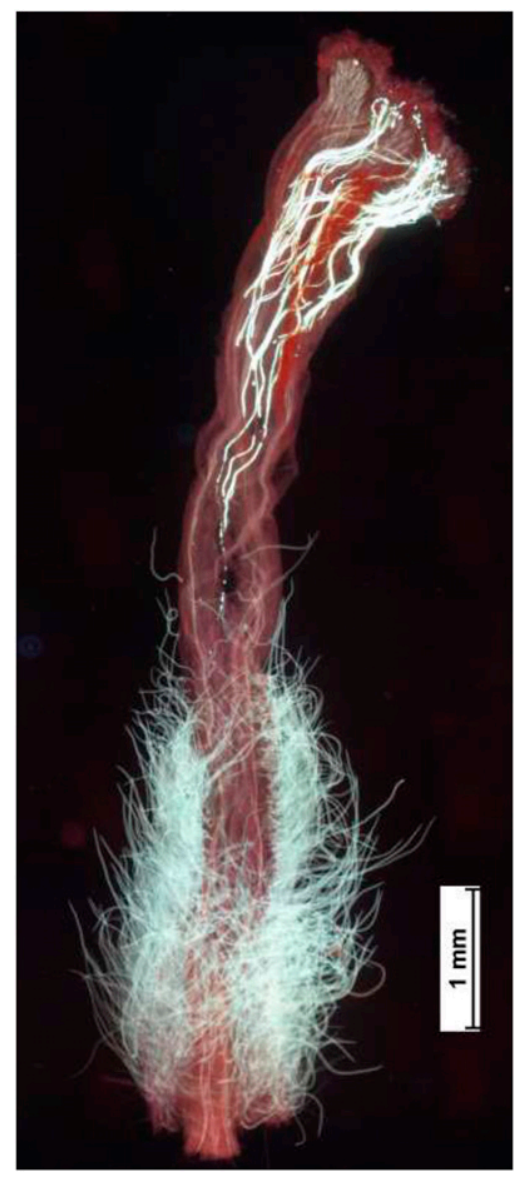

Fig. 1. 'Thunderchild' pollen tube growth in a 'Fuji' apple $24 \mathrm{~h}$ after pollination at a constant temperature of $24^{\circ} \mathrm{C}$, visualized with water-soluble fluorescent solution containing $0.01 \%$ aniline blue dye in $0.067 \mathrm{M} \mathrm{K}_{2} \mathrm{HPO}_{4}$ and magnified $10 \times$ using a light microscope and a fluorescent light source.

removed from the tree in the order they were pollinated and placed into glass vials filled with a 5\% aqueous sodium sulfite (Amresco, Solon, $\mathrm{OH}$ ) solution.

Storage vials containing the flowers were placed in boiling water for $20 \mathrm{~min}$ to soften the tissue. The pistillate portions were then excised from each flower and rinsed with distilled water. The styles were individually detached from the ovary using forceps and scalpel. The styles were stained with a water-soluble fluorescent solution containing $0.01 \%$ aniline blue dye (MP Biomedicals, Solon, $\mathrm{OH}$ ) in $0.067 \mathrm{M} \mathrm{K}_{2} \mathrm{HPO}_{4}$ for pollen tube visualization, then pressed between two microscope slides (Embree and Foster, 1999). Slides were viewed at $10 \times$ and $40 \times$ with a light microscope (Eclipse $\mathrm{Ci}$; Nikon, 
Table 2. Mean apple pollen tube length, mean style length, and mean percent of style length covered by pollen tube growth of 'Cripps Pink', 'Fuji', and 'Golden Delicious' nonpollinated control blossom styles for each temperature evaluation (12, 18, 24, and 30 $\left.{ }^{\circ} \mathrm{C}\right)$.

\begin{tabular}{|c|c|c|c|c|c|c|c|c|c|}
\hline \multirow[b]{2}{*}{ Temp $\left({ }^{\circ} \mathrm{C}\right)$} & \multicolumn{3}{|c|}{ Cripps Pink } & \multicolumn{3}{|c|}{ Golden Delicious } & \multicolumn{3}{|c|}{ Fuji } \\
\hline & $\begin{array}{l}\text { Pollen tube } \\
\text { length }(\mathrm{mm})\end{array}$ & $\begin{array}{c}\text { Style } \\
\text { length }(\mathrm{mm})\end{array}$ & $\begin{array}{c}\text { Style } \\
\text { length (\%) }\end{array}$ & $\begin{array}{l}\text { Pollen tube } \\
\text { length }(\mathrm{mm})\end{array}$ & $\begin{array}{c}\text { Style } \\
\text { length }(\mathrm{mm})\end{array}$ & $\begin{array}{c}\text { Style } \\
\text { length (\%) }\end{array}$ & $\begin{array}{l}\text { Pollen tube } \\
\text { length }(\mathrm{mm})\end{array}$ & $\begin{array}{c}\text { Style } \\
\text { length }(\mathrm{mm})\end{array}$ & $\begin{array}{c}\text { Style } \\
\text { length }(\%) \\
\end{array}$ \\
\hline 12 & 0.0 & 9.1 & 0.0 & 0.0 & 9.6 & 0.0 & 0.0 & 8.9 & 0.0 \\
\hline 24 & 1.0 & 9.1 & 11.1 & 0.3 & 10.1 & 2.8 & 0.57 & 10.4 & 5.1 \\
\hline 30 & 0.2 & 9.4 & 2.2 & 0.1 & 10.7 & 0.7 & 0.24 & 10.7 & 1.6 \\
\hline
\end{tabular}

Tokyo, Japan) and fluorescent light source (Intensilight C-HGFI; Nikon). Histological examination for each individual style was conducted as described in Yoder et al. (2009) and Yoder et al. (2013), and included pollen germination/tube growth on the stigmatic surface $(0 \%$ to $100 \%$ of visible stigmatic surface covered with pollen), number of pollen tubes penetrating the base of the stigma, length of the longest pollen tube, style length, and the number of pollen tubes that grew to the base of the style.

Mean separation between pollen tube growth on nonpollinated control styles and experimental styles was performed using the Kruskal-Wallis test (JMP; SAS Institute, Cary, NC). Statistical differences among paternal cultivar pollen tube growth length were determined using the SAS PROCMIXED procedure (SAS Institute). The statistical model included the fixed effects of temperature $\left(12,18,24\right.$, and $\left.30{ }^{\circ} \mathrm{C}\right)$, maternal cultivar (Golden Delicious, Fuji, and Cripps Pink), paternal cultivar (Evereste, Indian Summer, Selkirk, Snowdrift, and Thunderchild), random effects of blossom and style, and interactions among maternal $\times$ paternal and maternal $\times$ paternal $\times$ temperature. Due to the highly significant and inclusive interaction term, maternal $\times$ paternal $\times$ temperature $(P<0.0001)$ and previous research evaluating the relationship between pollen tube growth and temperature, the maternal $\times$ temperature and paternal $\times$ temperature interactions were not included in the model. A two-way analysis of variance [ANOVA (JMP)] was used to analyze differences among maternal cultivars, paternal cultivars, and the maternal $\times$ paternal interaction at each temperature.

Differences in the percent of styles with paternal pollen tubes reaching the base were analyzed using the GLIMMIX procedure of SAS (SAS Institute). The fixed effects included in the model were temperature $\left(24\right.$ and $\left.30^{\circ} \mathrm{C}\right)$, maternal cultivar (Cripps Pink, Fuji, and Golden Delicious), and paternal cultivar (Evereste, Indian Summer, Selkirk, Snowdrift, and Thunderchild). Interaction terms were not used in the model because they were not significant.

\section{Results}

Pollen collected from 'Thunderchild', 'Selkirk', and 'Indian Summer' had germination rates of $90 \%, 85 \%$, and $75 \%$, respectively, and pollen collected from 'Snowdrift' and 'Evereste' each had a $65 \%$ germination rate (Table 1 ). We used fluorescent microscopy to visualize pollen tubes as bright blue colored structures within the red to purple colored pistillate tissue (Fig. 1). Pubescence at the base of the style also fluoresces, but is different in structure and easily differentiated from the pollen tubes.
Table 3. Main effects and interactions, paternal cultivar, maternal cultivar, temperature, maternal cultivar $\times$ paternal cultivar, and maternal cultivar $\times$ paternal cultivar $\times$ temperature, included in the PROC MIXED (SAS Institute) model to analyze paternal crabapple pollen tube growth length after $24 \mathrm{~h}$ in a growth chamber.

\begin{tabular}{lrrr}
\hline Effects and interactions & df & F ratio & $P<\mathrm{F}$ \\
\hline Paternal & 4 & 33.37 & $<0.0001$ \\
Maternal & 2 & 14.60 & $<0.0001$ \\
Temperature & 3 & 762.68 & $<0.0001$ \\
Maternal $\times$ paternal & 8 & 2.29 & 0.0194 \\
Maternal $\times$ paternal $\times$ temperature & 42 & 4.68 & $<0.0001$ \\
\hline
\end{tabular}

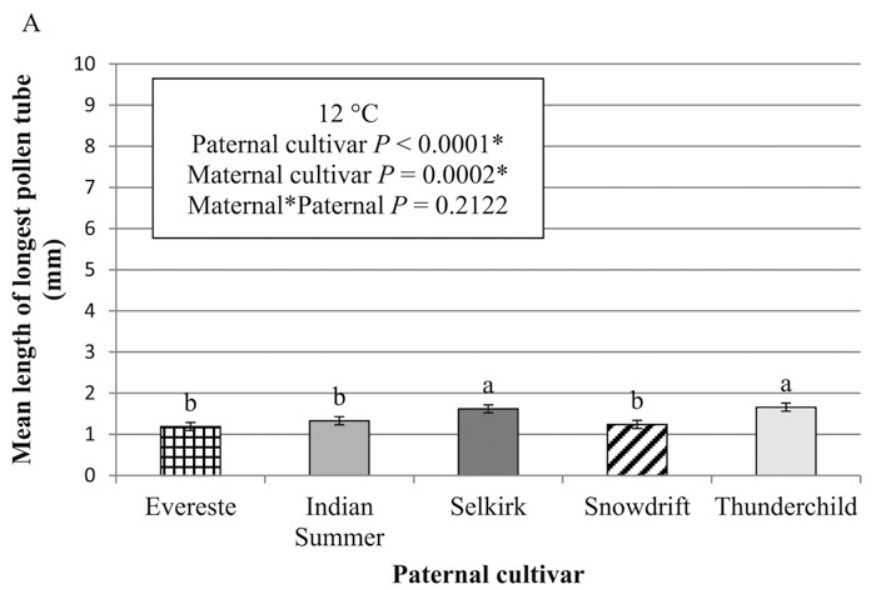

B

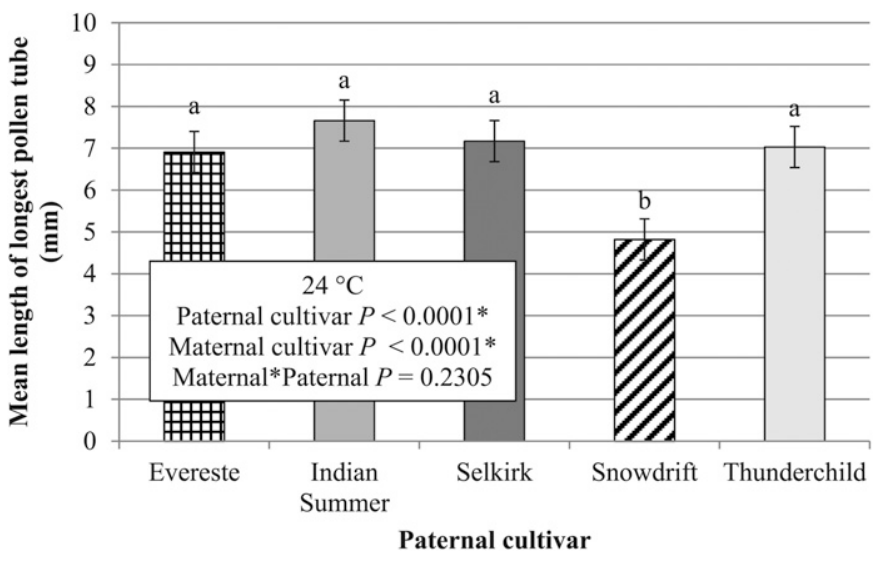

Fig. 2. Mean apple pollen tube growth length of cultivars Evereste, Indian Summer, Selkirk, Snowdrift, and Thunderchild in all evaluated maternal cultivars (Cripps Pink, Golden Delicious, and Fuji combined) styles $24 \mathrm{~h}$ after pollination in growth chambers kept at (A) $12{ }^{\circ} \mathrm{C}$ and (B) $24^{\circ} \mathrm{C}$. Statistical analysis by analysis of variance and post hoc mean separation by Tukey's honestly significant difference (JMP). Each value represents 105 observations. Error bars represent SE. 
Pollen tubes were found in the styles of nonpollinated control flowers during the 18,24 , and $30{ }^{\circ} \mathrm{C}$ trial, but not the $12{ }^{\circ} \mathrm{C}$ (Table 2). The pollen tubes found in control blossom styles were significantly shorter than those found growing in hand-pollinated treatment styles regardless of maternal cultivar or temperature $(P<$ $0.0001)$. Due to this highly significant difference, the pollen tube growth of the five paternal cultivars was analyzed without further comparison with control blossoms. The average style lengths for 'Cripps Pink', 'Golden Delicious', and 'Fuji' were 9.2, 10.1, and $9.7 \mathrm{~mm}$, respectively.

All effects and interactions (temperature, maternal, paternal, maternal $\times$ paternal, maternal $\times$ paternal $\times$ temperature) were significant in the mixed model analyzing the average pollen tube growth length (Table 3). The two-way ANOVA from each temperature trial revealed significant maternal $\times$ paternal interactions for the 18 and $30{ }^{\circ} \mathrm{C}$ trials, but not for the 12 and $24^{\circ} \mathrm{C}$ trials (Fig. 2).

At $12{ }^{\circ} \mathrm{C}$, the maternal $\times$ paternal interaction was not significant, so the pollen tube growth in maternal cultivar styles was averaged to better assess the pollen tube growth of the paternal cultivars (Fig. 2A). Across all maternal cultivars at $12{ }^{\circ} \mathrm{C}$, Selkirk and Thunderchild pollen tubes grew further than Evereste, Indian Summer, and Snowdrift pollen tubes.

At $18{ }^{\circ} \mathrm{C}$, in 'Fuji' flowers, 'Indian Summer', 'Selkirk', and 'Thunderchild' pollen tubes grew, on average, 33\% further down the style than 'Evereste' and 'Snowdrift' pollen tubes; and in 'Golden Delicious' styles, 'Selkirk' pollen tubes grew, on average, $38 \%$ further
Table 4. Mean pollen tube growth length and standard errors of paternal crabapple cultivars after $24 \mathrm{~h}$ in a growth chamber, in maternal cultivar styles, at four temperatures, $12,18,24$, and $30^{\circ} \mathrm{C}$. The mean pollen tube growth length is represented in each table, but arranged so differences in (A) paternal cultivars, Evereste, Indian Summer, Selkirk, Snowdrift, and Thunderchild; (B) maternal cultivars, Cripps Pink, Fuji, and Golden Delicious; and (C) temperatures can be separately evaluated. Cultivars or temperatures not connected linearly by the black boxes in the same column are significantly different. Statistical analysis completed by PROC MIXED. Means represent 35 observations and are significant at $P \leq 0.05$.

\begin{tabular}{|c|c|c|c|c|c|c|c|c|}
\hline & & & & & & & & \\
\hline Maternal & Paternal & $\begin{array}{l}\text { Pollen } \\
\text { tube length } \\
\text { (mm) }\end{array}$ & Paternal & $\begin{array}{l}\text { Pollen } \\
\text { tube length } \\
\text { (mm) }\end{array}$ & Paternal & $\begin{array}{l}\text { Pollen } \\
\text { tube length } \\
\text { (mm) }\end{array}$ & Paternal & $\begin{array}{l}\text { Pollen } \\
\text { tube length } \\
(\mathrm{mm})\end{array}$ \\
\hline \multirow[t]{5}{*}{ Cripps Pink } & SK & $1.8 \pm 0.1$ & $\mathrm{TC}$ & $4.6 \pm 0.4$ & IS & $7.5 \pm 0.6$ & IS & $8.4 \pm 0.6$ \\
\hline & TC & $1.7 \pm 0.2$ & IS & $3.9 \pm 0.4$ & SK & $7.3 \pm 0.5$ & SK & $7.8 \pm 0.5$ \\
\hline & SD & $1.6 \pm 0.2$ & SD & $3.6 \pm 0.4$ & EV & $6.5 \pm 0.6$ & $\mathrm{TC}$ & $7.7 \pm 0.6$ \\
\hline & IS & $1.6 \pm 0.2$ & SK & $3.5 \pm 0.4$ & $\mathrm{TC}$ & $6.1 \pm 0.6$ & EV & $7.4 \pm 0.5$ \\
\hline & EV & $1.4 \pm 0.1$ & EV & $3.4 \pm 0.3$ & SD & $6.1 \pm 0.6$ & SD & $5.0 \pm 0.6$ \\
\hline \multirow[t]{5}{*}{ Fuji } & TC & $1.5 \pm 0.1$ & TC & $5.3 \pm 0.4$ & IS & $6.9 \pm 0.4$ & $\mathrm{TC}$ & $9.0 \pm 0.5$ \\
\hline & SK & $1.4 \pm 0.1$ & SK & $5.0 \pm 0.3$ & EV & $6.3 \pm 0.3$ & IS & $6.6 \pm 0.6$ \\
\hline & IS & $1.2 \pm 0.1$ & IS & $4.5 \pm 0.4$ & $\mathrm{TC}$ & $6.2 \pm 0.4$ & SK & $6.4 \pm 0.7$ \\
\hline & EV & $1.2 \pm 0.1$ & EV & $3.0 \pm 0.2$ & SK & $6.1 \pm 0.4$ & EV & $6.3 \pm 0.6$ \\
\hline & SD & $1.1 \pm 0.1$ & SD & $2.7 \pm 0.3$ & SD & $4.8 \pm 0.5$ & SD & $3.5 \pm 0.4$ \\
\hline \multirow[t]{5}{*}{ Golden Delicious } & TC & $1.8 \pm 0.2$ & SK & $4.3 \pm 0.4$ & $\mathrm{TC}$ & $8.6 \pm 0.4$ & SK & $9.2 \pm 0.5$ \\
\hline & SK & $1.6 \pm 0.1$ & TC & $3.5 \pm 0.3$ & IS & $8.4 \pm 0.5$ & IS & $8.9 \pm 0.8$ \\
\hline & IS & $1.2 \pm 0.1$ & IS & $3.5 \pm 0.4$ & SK & $7.8 \pm 0.5$ & $\mathrm{TC}$ & $8.6 \pm 0.3$ \\
\hline & SD & $1.1 \pm 0.1$ & SD & $3.3 \pm 0.3$ & EV & $7.8 \pm 0.5$ & EV & $7.8 \pm 0.5$ \\
\hline & EV & $1.0 \pm 0.1$ & EV & $2.7 \pm 0.3$ & SD & $6.0 \pm 0.6$ & SD & $5.3 \pm 0.6$ \\
\hline
\end{tabular}

$\underline{\mathbf{B}}$

\begin{tabular}{|c|c|c|c|c|c|c|c|c|}
\hline Temp $\left({ }^{\circ} \mathrm{C}\right)$ & & 12 & & 18 & & 24 & & 30 \\
\hline Paternal & Maternal & $\begin{array}{l}\text { Pollen } \\
\text { tube length } \\
(\mathrm{mm})\end{array}$ & Maternal & $\begin{array}{l}\text { Pollen } \\
\text { tube length } \\
(\mathrm{mm})\end{array}$ & Maternal & $\begin{array}{l}\text { Pollen } \\
\text { tube length } \\
\text { (mm) }\end{array}$ & Maternal & $\begin{array}{l}\text { Pollen } \\
\text { tube length } \\
\text { (mm) }\end{array}$ \\
\hline \multirow{3}{*}{ Evereste } & $\mathrm{CP}$ & $1.4 \pm 0.1$ & $\mathrm{CP}$ & $3.4 \pm 0.3$ & GD & $7.8 \pm 0.5$ & GD & $7.8 \pm 0.5$ \\
\hline & FJ & $1.2 \pm 0.1$ & FJ & $2.7 \pm 0.2$ & $\mathrm{CP}$ & $6.5 \pm 0.6$ & $\mathrm{CP}$ & $7.4 \pm 0.5$ \\
\hline & GD & $1.0 \pm 0.1$ & GD & $2.9 \pm 0.3$ & FJ & $6.3 \pm 0.3$ & FJ & $6.3 \pm 0.6$ \\
\hline \multirow{3}{*}{$\begin{array}{c}\text { Indian } \\
\text { Summer }\end{array}$} & $\mathrm{CP}$ & $1.6 \pm 0.2$ & FJ & $4.5 \pm 0.4$ & GD & $8.4 \pm 0.5$ & GD & $8.9 \pm 0.8$ \\
\hline & FJ & $1.2 \pm 0.1$ & $\mathrm{CP}$ & $3.9 \pm 0.4$ & $\mathrm{CP}$ & $7.5 \pm 0.6$ & $\mathrm{CP}$ & $7.4 \pm 0.6$ \\
\hline & GD & $1.2 \pm 0.1$ & GD & $2.7 \pm 0.4$ & FJ & $6.9 \pm 0.4$ & FJ & $6.2 \pm 0.6$ \\
\hline \multirow{3}{*}{ Selkirk } & $\mathrm{CP}$ & $1.8 \pm 0.1$ & FJ & $4.9 \pm 0.3$ & GD & $7.8 \pm 0.5$ & GD & $9.2 \pm 0.5$ \\
\hline & GD & $1.6 \pm 0.1$ & GD & $4.3 \pm 0.4$ & $\mathrm{CP}$ & $7.3 \pm 0.5$ & $\mathrm{CP}$ & $7.8 \pm 0.5$ \\
\hline & FJ & $1.4 \pm 0.1$ & $\mathrm{CP}$ & $3.5 \pm 0.4$ & FJ & $6.2 \pm 0.4$ & FJ & $6.4 \pm 0.7$ \\
\hline \multirow{3}{*}{ Snowdrift } & $\mathrm{CP}$ & $1.6 \pm 0.2$ & $\mathrm{CP}$ & $3.6 \pm 0.4$ & $\mathrm{CP}$ & $6.1 \pm 0.6$ & GD & $5.3 \pm 0.6$ \\
\hline & GD & $1.1 \pm 0.1$ & GD & $3.3 \pm 0.3$ & GD & $6.0 \pm 0.6$ & $\mathrm{CP}$ & $5.0 \pm 0.6$ \\
\hline & FJ & $1.1 \pm 0.1$ & FJ & $2.6 \pm 0.3$ & FJ & $4.8 \pm 0.5$ & FJ & $3.5 \pm 0.4$ \\
\hline \multirow{3}{*}{ Thunderchild } & GD & $1.8 \pm 0.2$ & FJ & $5.3 \pm 0.4$ & GD & $8.6 \pm 0.4$ & FJ & $9.0 \pm 0.5$ \\
\hline & $\mathrm{CP}$ & $1.7 \pm 0.2$ & $\mathrm{CP}$ & $4.6 \pm 0.4$ & $\mathrm{CP}$ & $6.1 \pm 0.6$ & GD & $8.6 \pm 0.3$ \\
\hline & FJ & $1.5 \pm 0.1$ & GD & $3.5 \pm 0.3$ & FJ & $6.1 \pm 0.4$ & $\mathrm{CP}$ & $7.7 \pm 0.6$ \\
\hline
\end{tabular}

Continued next page 
Table 4. Continued.

\begin{tabular}{|c|c|c|c|c|c|c|}
\hline \multirow[t]{2}{*}{ Maternal } & \multicolumn{2}{|r|}{ Cripps Pink } & \multicolumn{2}{|r|}{ Fuji } & \multicolumn{2}{|c|}{ Golden Delicious } \\
\hline & Temp ${ }^{\circ} \mathrm{C}$ & $\begin{array}{l}\text { Pollen tube length } \\
(\mathrm{mm})\end{array}$ & Temp ${ }^{\circ} \mathrm{C}$ & $\begin{array}{l}\text { Pollen tube length } \\
(\mathrm{mm})\end{array}$ & Temp ${ }^{\circ} \mathrm{C}$ & $\begin{array}{l}\text { Pollen tube length } \\
(\mathrm{mm})\end{array}$ \\
\hline \multirow{4}{*}{ Evereste } & 12 & $1.4 \pm 0.1$ & 12 & $1.2 \pm 0.1$ & 12 & $1.0 \pm 0.1$ \\
\hline & 18 & $3.4 \pm 0.3$ & 18 & $2.9 \pm 0.2$ & 18 & $2.7 \pm 0.3$ \\
\hline & 24 & $6.5 \pm 0.6$ & 24 & $6.3 \pm 0.3$ & 24 & $7.8 \pm 0.5$ \\
\hline & 30 & $7.4 \pm 0.5$ & 30 & $6.3 \pm 0.6$ & 30 & $7.8 \pm 0.5$ \\
\hline \multirow{4}{*}{ Indian Summer } & 12 & $1.6 \pm 0.2$ & 12 & $1.2 \pm 0.1$ & 12 & $1.2 \pm 0.1$ \\
\hline & 18 & $3.9 \pm 0.4$ & 18 & $4.5 \pm 0.4$ & 18 & $3.5 \pm 0.4$ \\
\hline & 24 & $7.5 \pm 0.6$ & 24 & $6.9 \pm 0.4$ & 24 & $8.4 \pm 0.5$ \\
\hline & 30 & $8.4 \pm 0.6$ & 30 & $6.6 \pm 0.6$ & 30 & $8.9 \pm 0.8$ \\
\hline \multirow{4}{*}{ Selkirk } & 12 & $1.8 \pm 0.1$ & 12 & $1.4 \pm 0.1$ & 12 & $1.6 \pm 0.1$ \\
\hline & 18 & $3.5 \pm 0.4$ & 18 & $4.9 \pm 0.3$ & 18 & $4.3 \pm 0.4$ \\
\hline & 24 & $7.3 \pm 0.5$ & 24 & $6.2 \pm 0.4$ & 24 & $7.8 \pm 0.5$ \\
\hline & 30 & $7.8 \pm 0.5$ & 30 & $6.4 \pm 0.7$ & 30 & $9.2 \pm 0.5$ \\
\hline \multirow{4}{*}{ Snowdrift } & 12 & $1.6 \pm 0.2$ & 12 & $1.1 \pm 0.1$ & 12 & $1.1 \pm 0.1$ \\
\hline & 18 & $3.6 \pm 0.4$ & 18 & $2.6 \pm 0.3$ & 18 & $3.3 \pm 0.3$ \\
\hline & 24 & $6.1 \pm 0.6$ & 24 & $4.8 \pm 0.5$ & 24 & $6.0 \pm 0.6$ \\
\hline & 30 & $5.0 \pm 0.6$ & 30 & $3.5 \pm 0.4$ & 30 & $5.3 \pm 0.6$ \\
\hline \multirow{4}{*}{ Thunderchild } & 12 & $1.7 \pm 0.2$ & 12 & $1.5 \pm 0.1$ & 12 & $1.8 \pm 0.2$ \\
\hline & 18 & $4.6 \pm 0.4$ & 18 & $5.3 \pm 0.4$ & 18 & $3.5 \pm 0.3$ \\
\hline & 24 & $6.1 \pm 0.6$ & 24 & $6.1 \pm 0.4$ & 24 & $8.6 \pm 0.4$ \\
\hline & 30 & $7.7 \pm 0.6$ & 30 & $9.0 \pm 0.5$ & 30 & $8.6 \pm 0.3$ \\
\hline
\end{tabular}

base of one 'Fuji' and three 'Cripps Pink' styles, and a 'Selkirk' pollen tube grew to the base of one 'Cripps Pink' style (data not shown). The maternal $\times$ paternal interaction was not significant, indicating the percent of paternal pollen tubes reaching the base of the style was similar for every maternal $\times$ paternal combination. Nineteen percent of 'Fuji', 35\% of 'Golden Delicious', and $37 \%$ of 'Cripps Pink' styles had pollen tubes growing to the base. 'Indian Summer' pollen tubes most frequently grew to the base of the style, a $32 \%$ increase over the success rate of 'Snowdrift' pollen tubes (Table 5).

\section{Discussion}

On average, pollen tube length in the control blossoms did not exceed one-third of the average style length, indicating pollen tubes found in styles likely resulted from self-pollination. Self-pollinated flowers of selfsterile apple cultivars will initiate pollen tube growth, but the tubes

than 'Evereste' pollen tubes (Table 4A). In 'Cripps Pink' styles, 'Thunderchild' pollen tubes grew further than those of 'Selkirk' and 'Evereste'. At $18{ }^{\circ} \mathrm{C}$, 'Thunderchild' pollen tubes grew further in 'Fuji' styles than in 'Golden Delicious' styles, and 'Selkirk' pollen tubes grew further in 'Fuji' styles than those of 'Cripps Pink' (Table 4B).

At $24{ }^{\circ} \mathrm{C}$, the maternal $\times$ paternal interaction was not significant, indicating paternal pollen tube growth was similar across all three maternal cultivars (Fig. 2B). 'Snowdrift' pollen tube length was over $29 \%$ shorter at $24{ }^{\circ} \mathrm{C}$ than all other paternal cultivars.

At $30{ }^{\circ} \mathrm{C}$, in 'Fuji' styles, 'Thunderchild' pollen tubes grew $27 \%$ further, and Snowdrift pollen tubes grew $44 \%$ less than the other three paternal cultivars (Table 4A). In 'Golden Delicious' styles, 'Indian Summer' and 'Selkirk' pollen tubes grew significantly further than 'Evereste' and 'Snowdrift' pollen tubes. In 'Cripps Pink' styles, the average pollen tube length of 'Snowdrift' was $32 \%$ less than the pollen tubes of the other four paternal cultivars. At $30^{\circ} \mathrm{C}$, pollen tubes in 'Fuji' styles were shorter for 'Evereste', 'Indian Summer', and 'Selkirk', and longer for 'Thunderchild' (Table 4B).

Pollen tube growth increased from 12 to $24{ }^{\circ} \mathrm{C}$ for all maternal by paternal combinations (Table 4C). There were only two maternal $\times$ paternal combinations when there was a statistically significant increase in pollen tube growth between 24 and $30^{\circ} \mathrm{C}$.

None of the crabapple genotypes had pollen tubes that reached the base of any maternal cultivar style at $12{ }^{\circ} \mathrm{C}$ (data not shown). At $18{ }^{\circ} \mathrm{C}$, 'Thunderchild' pollen tubes grew to the are often halted in the top third of the style by proteins formed when the $S$-alleles of the style and those of the pollen tubes are recognized as equal (Stösser et al., 1996). Self-pollination may have occurred when the flower petals still enclosed the sexual organs or during anther removal. Similar results were also found by Yoder et al. (2009) when 'Golden Delicious' pollen tube growth was initiated in the style of 'Golden Delicious' flowers, but never grew past one-third of the style length.

The significant $(P<0.0001)$ three-way interaction (maternal $\times$ paternal $\times$ temperature) suggests that pollen tube growth rates are affected by stylar features of maternal cultivars, and that this relationship is further modified by the temperature under which pollen tube growth occurs. The pollen tube length increased up to $24{ }^{\circ} \mathrm{C}$, but, with the exception of 'Selkirk' $\times$ 'Golden Delicious' and 'Thunderchild' $\times$ 'Fuji', pollen tube growth did not increase further between the 24 and $30{ }^{\circ} \mathrm{C}$. This indicates that the maximum temperature of pollen tubes from most of the combinations we tested was between 24 and $30^{\circ} \mathrm{C}$. Yoder et al. (2009) showed an increase in the pollen tube growth of 'Snowdrift' with increasing day/ night temperatures up to $24 / 7{ }^{\circ} \mathrm{C}$, but they did not evaluate temperatures as high as $30^{\circ} \mathrm{C}$.

The paternal cultivar pollen tubes often had different growth rates in the three evaluated maternal cultivars. For example, during the $24{ }^{\circ} \mathrm{C}$ trial, pollen tubes from all paternal cultivars grew further in Golden Delicious styles compared with Fuji styles. The same result was found at $30^{\circ} \mathrm{C}$ for four of the five crabapples-'Thunderchild' being the exception. These findings might relate to the maternal cultivar, more so than the paternal cultivar, which would be in agreement with previous 
Table 5. The percentage of apple styles with paternal cultivars Evereste, Indian Summer, Selkirk, Snowdrift, and Thunderchild pollen tubes growing to the base, and the percent of maternal cultivars, Cripps Pink, Fuji, and Golden Delicious, styles with pollen tubes growing to the base. Data are means from the 24 and $30^{\circ} \mathrm{C}$ temperature evaluations. Mean separation within column by PROC GLIMMIX.

\begin{tabular}{lclc}
\hline Paternal cultivar & Styles with pollen tubes growing to base (\%) & Maternal cultivar & Styles with pollen tubes growing to base (\%) \\
\hline Evereste & $23 \mathrm{~cd}$ & Cripps Pink & $37 \mathrm{a}$ \\
Indian Summer & $44 \mathrm{a}$ & Fuji & $19 \mathrm{~b}$ \\
Selkirk & $36 \mathrm{bc}$ & Golden Delicious & $35 \mathrm{a}$ \\
Snowdrift & $12 \mathrm{~d}$ & & \\
Thunderchild & $39 \mathrm{ab}$ & P value & 0.0008 \\
$P$ value & $<0.0001$ & F ratio & 6.2 \\
F ratio & 7.42 & & \\
\hline
\end{tabular}

research suggesting maternal genotype can affect pollen tube growth and fertilization (Kron and Husband, 2006; Stott, 1972). In a preliminary study, Yoder et al. (2013) noted as much as a 3 -fold difference among the pollen tube growth rates of different apple cultivars. In our study, pollen tube growth differences were often less than 3 -fold, though statistical differences did exist at 18,24 , and $30^{\circ} \mathrm{C}$.

The success rate of pollen tubes reaching the base of the style was not analyzed at 12 and $18{ }^{\circ} \mathrm{C}$ due to the low numbers of pollen tubes reaching the base. This was expected based on previous research evaluating the pollen tube growth of multiple species at low temperatures (Chen and Gibson, 1973; Hedhly et al., 2005; Sorkheh et al., 2011). The mean pollen tube length of 'Indian Summer' and 'Selkirk' was not significantly different at 24 or $30^{\circ} \mathrm{C}$, but 'Indian Summer' had a higher percentage of pollen tubes growing to the base of the style. 'Selkirk' pollen tubes that grew close to the base are not accounted for in the success rate data. Our study results indicate that certain pollen genotypes are more likely to have at least one pollen tube grow to the base of the style, even when the mean length of all the measured pollen tubes was not longer than that of the other genotypes.

Although the relationships between paternal pollen tube growth and maternal cultivar styles were inconsistent, certain trends were ascertained. 'Snowdrift', the crabapple used to develop the pollen tube growth model, often had less pollen tube growth than the other four cultivars, and therefore may not be the optimal pollinizer in regions with consistently warm temperatures during bloom. At $12{ }^{\circ} \mathrm{C}$, 'Thunderchild' and 'Selkirk' pollen tubes grew further than those of 'Indian Summer', 'Evereste', and 'Snowdrift' (Fig. 2B). However, the substantial increase in pollen tube growth at warmer temperatures minimized overall statistical differences.

The increased growth of 'Selkirk' and 'Thunderchild' pollen tubes at colder temperatures may be related to the earlier flowering and shorter phenology of these cultivars. At the AREC in Spring 2015, 'Selkirk' and 'Thunderchild' were the first of the five crabapple cultivars to bloom and the time between the first bloom and petal fall was only $7 \mathrm{~d}$ (Table 1). Flowering time may be related to pollen tube growth rates among Malus species, but more data are needed to support that conclusion.

In addition, 'Evereste' and 'Snowdrift' were the only two cultivars evaluated with white flowers (Table 1). These two cultivars had the lowest germination rates, the lowest percent of pollen tubes reaching the base of the style, and most often the shortest pollen tube length. Flower color has been reported to affect pollen tube growth rate of Mirabilis jalapa, where pollen tubes of red- and magenta-flowered genotypes grew further than those of yellow- and pink-flowered genotypes (Berardi et al., 2013). The evolutionary relationship between petal color and pollen tube growth rate is unclear, and a much larger study would be required to establish a causal relationship in apple.

The presence of multiple donor genotypes has been shown to increase fecundity in apple (Kron and Husband, 2006). It is possible that some of the crabapple genotypes in our experiment use more than one strategy to outcompete other genotypes and achieve fertilization, meaning that pollen tube growth rates may only be one of many factors involved in understanding our results. Future studies should compare the pollen tube growth rates of single vs. multiple pollen sources.

Apple growers who use the pollen tube growth model to apply blossom-thinning chemicals rely on pollen tube growth rate equations that were developed based on 'Snowdrift' pollen. As new pollinizers replace 'Snowdrift', the pollen tube growth model should be reevaluated to determine if changes to the algorithms are warranted. In addition, our results suggest that growers could select pollinizer cultivars based on their specific management goals. For example, a grower who prefers to finish thinning as early as possible may want to select a pollinizer with a faster pollen tube growth rate; such as, 'Thunderchild' or 'Selkirk'. With this project, we determined the pollen tube growth rate is complex and influenced by both maternal and paternal cultivars, as well as by temperature.

\section{Literature Cited}

Adams, J. 1916. On the germination of the pollen grains of apple and other fruit trees. Bot. Gaz. 61:131-147.

Berardi, A.E., F.M. Frey, E.M. Denton, and J.H. Wells. 2013. Betalain color morphs exhibit differential growth, defensive ability, and pollen tube growth rates in Miribilis jalapa (Nyctaginaceae). Intl. J. Plant Sci. 174:1229-1238.

Chapman, P.J. and G.A. Catlin. 1976. Growth stages in fruit treesFrom dormant to fruit set. N.Y.'s Food Life Sci. Bul. No. 58.

Chen, C. and P.B. Gibson. 1973. Effect of temperature on pollen-tube growth in Trifolium repens after cross- and self-pollinations. Crop Sci. 13:563-566.

Dennis, F.G., Jr. 2000. The history of fruit thinning. Plant Growth Regulat. 31:1-16.

Dennis, F., Jr. 2003. Flowering, pollination and fruit set and development, p. 153-166. In: D.C. Ferree (ed.). Apples botany production and uses. CAB Intl., Cambridge, UK.

Embree, C.G. and A. Foster, Jr. 1999. Effects of coatings and pollenicides on pollen tube growth through the stigma and style of 'McIntosh' apple blossoms. J. Tree Fruit Production 2:19-32.

Fitzgerald, T. 2005. Pollination in fruit trees. Washington State Spokane County Ext. Bul. C105. 
Hansen, M. 2014. Is there a better crab apple pollinizer? 19 Mar. 2014. $<$ http://www.goodfruit.com/is-there-a-better-crab-apple-pollinizer/>.

Hedhly, A., J.I. Hormaza, and M. Herrero. 2005. The effect of temperature on pollen germination, pollen tube growth, and stigmatic receptivity in peach. Plant Biol. 7:476-483.

Jackson, J.E. 2003. Biology of apples and pears. Cambridge Univ. Press, Cambridge, MA.

Kron, P. and B.C. Husband. 2006. The effects of pollen diversity on plant reproduction: Insights from apple. Sex. Plant Reprod. 19:125131.

Lehnert, R. 2014. Pollen tube growth model makes thinning more precise. 19 Mar. 2014. <http://www.goodfruit.com/pollen-tubegrowth-model-makes-thinning-more-precise/>.

McArtney, S., J. Palmer, S. Davies, and S. Seymour. 2006. Effects of lime sulfur and fish oil on pollen tube growth, leaf photosynthesis, and fruit set in apple. HortScience 41:357-360.

Peck, G.M., L.D. Combs, C.N. DeLong, and K.S. Yoder. 2016. Precision apple flower thinning using organically-approved chemicals. Acta Hort. (In press).

Ramírez, F. and T.L. Davenport. 2013. Apple pollination: A review. Sci. Hort. 162:188-203.
Sorkheh, K., B. Shiran, V. Rouhi, and M. Khodambashi. 2011. Influence of temperature on the in vitro pollen germination and pollen tube growth of various native Iranian almonds (Prunus L. spp.) species. Trees (Berl.) 25:809-822.

Stösser, R., W. Hartmann, and S.F. Anvari. 1996. General aspects of pollination and fertilization of pome and stone fruit. Acta Hort. 423:15-22.

Stott, K.G. 1972. Pollen germination and pollen-tube characteristics in a range of apple cultivars. J. Hort. Sci. 47:191-198.

Williams, R.R. 1965. The effect of summer nitrogen applications on the quality of apple blossom. J. Hort. Sci. 41:31-41.

Williams, R.R. and M. Maier. 1977. Pseudocompatibility after selfpollinating of the apple Cox's Orange Pippin. J. Hort. Sci. 52:475483.

Yoder, K., R. Yuan, L. Combs, R. Byers, J. McFerson, and T. Schmidt. 2009. Effects of temperature and the combination of liquid lime sulfur and fish oil on pollen germination, pollen tube growth, and fruit set in apples. HortScience 44:1277-1283.

Yoder, K.S., G.M. Peck, L.D. Combs, and R.E. Byers. 2013. Using a pollen tube growth model to improve apple bloom thinning for organic production. Acta Hort. 1001:207-214. 